\title{
An investigation into the opinions of pre-service teachers toward uses of digital storytelling in literacy education
}

\author{
Gül Özüdoğru* \\ Department of Educational Sciences, Faculty of Education, Kirşehir Ahi Evran University, \\ Kırşehir, Turkey, ORCID ID: 0000-0002-5128-1258
}

\section{Hasan Çakır}

Department of Computer Education and Instructional Technology, Gazi Faculty of Education, Gazi University, Ankara, Turkey, ORCID ID: 0000-0002-4499-9712

\begin{tabular}{|c|c|}
\hline Article history & the current study \\
\hline $\begin{array}{l}\text { Received: } \\
30.12 .2019\end{array}$ & $\begin{array}{l}\text { service teachers about the use of digital storytelling in literacy } \\
\text { education. This study was designed as a case study from qualitative }\end{array}$ \\
\hline $\begin{array}{l}\text { Received in revised form: } \\
12.02 .2020\end{array}$ & $\begin{array}{l}\text { research models. A total of } 32 \text { sophomore pre-service teachers studying } \\
\text { at the Department of Literacy Education in the Faculty of Education in } \\
\text { a state university during } 2015-2016 \text { academic year participated. The }\end{array}$ \\
\hline $\begin{array}{l}\text { Accepted: } \\
19.02 .2020\end{array}$ & $\begin{array}{l}\text { participants created digital stories based on the curriculum goals during } \\
\text { the instructional technologies and material design course. The data was }\end{array}$ \\
\hline $\begin{array}{l}\text { Key words: } \\
\text { Digital storytelling, pre-service } \\
\text { teacher, technology }\end{array}$ & $\begin{array}{l}\text { obtained from interviews with the students through the use of semi- } \\
\text { structured interview forms, researcher's field notes and students' } \\
\text { reflections. The obtained data were analyzed through content analysis. }\end{array}$ \\
\hline education & $\begin{array}{l}\text { The results of this study indicate that digital storytelling is perceived as } \\
\text { entertaining by pre-service teachers. Additionally, it was revealed that } \\
\text { scenario and dubbing are of great importance in practicing digital } \\
\text { storytelling. They also stated the importance of teaching with stories in } \\
\text { their own profession. Another finding emerging from this study is that } \\
\text { the participants had difficulty in using the software. Based on the } \\
\text { findings, it can be noted that it would be beneficial to take the opinions } \\
\text { of experts in selecting the software, optimize the technological } \\
\text { infrastructure and refer to interdisciplinary studies. The study concludes } \\
\text { with implications and recommendations for promoting digital } \\
\text { storytelling. }\end{array}$ \\
\hline
\end{tabular}

\section{Introduction}

\section{Digital storytelling}

Before the computers, movies, radios or even books, storytellers would tell stories. In this sense, stories have been used for such purposes as a form of entertaining, informing and instilling moral and social values for generations (Wan, Tanimoto, \& Templeton, 2008). Storytelling is a fundamental tool for handing down knowledge, beliefs, history and traditions 
to future generations (Smeda, Dakich \& Sharda, 2014; Suwardy, Pan, \& Seow, 2012). They indeed are effective means of simplifying the complex issues while teaching as well $(\mathrm{Ng} \&$ Nicholas, 2015). In addition to personating the imaginary worlds of children, stories improve reading, speaking, listening and writing skills along with lexical development in first and second language education (Ciğerci \& Gultekin, 2017). Today, designing stories are performed not merely through printed media or oral methods, but also using digital media tools (Del-Moral, Villalustre, \& Nerira, 2016).

Novel and developing technologies contribute to telling stories through usages of multimedia tools (Wan et al. 2008). Together with these technologies, storytelling art evolved into digital storytelling in 1990s, and thus digital storytelling came to the fore (Garrety, 2008). Digital storytelling is a modern way of telling stories through software, including multimedia tools such as visuals, audio, and music (Xu, Park, \& Baek, 2011). It is also an educational tool through which users can tell stories thanks to digital learning platforms supported by their own voices and visual images (Sezginsoy \& Şeker, 2016). Learning with multimedia tools encourages students to learn in-depth, by combining words with visual images, and educational messages included in multimedia tools enhance meaningful learning (Mayer, 2003). Apparently, there is a wide range of types of digital stories. Robin (2006), however, classified the most important ones under three categories. The first one is designed to inform or instruct the viewers on some certain topics such as maths, history, and instructional technologies. Another type of digital story is personal narrative that includes information about important issues in one's life. The last one is historical documentaries designed to investigate into dramatic events to get information about the past.

Previous research provides evidence that certain steps should be followed while designing digital stories (France \& Wakefield, 2011; Kajder, Bull, \& Albaugh, 2005; Cennamo, Ross, \& Ertmer, 2010). Cennamo et al. (2010) list these steps as writing the script, developing a storyboard, locating images, creating a digital story and sharing it with others. Semingson, Owens, Hurlbut and Robertson (2016) note that the elements of a good story must be taken into consideration while using digital storytelling alongside technology. Robin (2006) focused on seven essential elements of a digital story issued by Centre for Digital Storytelling (2005); point of view, dramatic question, emotional content, the gift of your voice, the power of the soundtrack, economy and pacing. Robin and Pierson (2005), on the other hand, expanded and added some new items and listed ten significant elements which are overall purpose of the study, the narrator's point of view, dramatic question/questions, the choice of content, clarity of voice, pacing of the narrative, use of a meaningful audio soundtrack, quality of the images, economy of the story detail and good grammar and language use. In this sense, it can be noted that there are some significant issues in digital storytelling as well as the quality of the images and grammar.

\section{Use of digital storytelling in literacy education in teacher education}

Digital storytelling which has steadily been gaining popularity is being practiced in several locations, such as libraries, schools, museums, community centres, medical and nursing schools apace with almost all educational settings beginning from kindergarten to graduate schools by teachers and students through a wide range of topics from art to zoology (Robin, 2016). Digital stories are powerful tools to raise awareness on such issues as social justice, social change, homelessness, agedness, mental health, and abuse besides personal experiences (Hewson, Danbrook, \& Sieppert, 2015). 
Although digital storytelling is used comprehensively in varying educational contexts, literacy education is one of the most common fields in which they are used (Wan et al. 2008; Yamaç \& Ulusoy, 2016). Developing such activities as reading, speaking, writing and listening from the beginning of primary school is of vital importance in adapting to the digital world and first language education (Çocuk \& Yanpar Yelken, 2018). A systematic examination of literature has revealed that digital storytelling positively affects basic language skills (writing, reading, listening and speaking) (Ciğerci \& Gultekin, 2017; Keşli Dollar \& Tekiner Tolu, 2015; Tatlı \& Aksoy, 2017; Yamaç \& Ulusoy, 2016).

Digital storytelling particularly has an impact on writing skills since one of the most significant skills needed in digital storytelling is writing (Dogan, 2007). Since digital storytelling process requires individuals to be active in such steps as writing the script, editing, and shaping, they are considered beneficial for writing skills (Çıralı Sarıca \& Koçak Usluel, 2014). In fact, writing, one of the most fundamental language skills, is a significant part of the curriculum for students from primary to K-12 level (Semingson et al. 2016). For this reason, determining the writing self-efficacies of Turkish pre-service teachers are crucial in terms of education of future students (Batar \& Aydın, 2014).

Interdisciplinary studies are required for growing individuals as those with some necessary qualifications is the core purpose of the literacy education (Bağc1, 2010). At this precise point, instructional technologies can be considered as a suitable media for carrying out interdisciplinary studies. Further investigation into several missing points ignored in other scientific studies can actually provide beneficial results. For example, combining teachers' experiences and opinions with studies based on literacy education supported by technology will contribute to dealing with problematic issues (Egbert, Huff, Mcneil, Preuss \& Sellen, 2009). Nevertheless it is observed that studies on technology integration mostly examine opinions of in-service teachers rather than pre-service teachers who would be in charge of integration of technology into teaching in the future (Çakır \& Yıldırım, 2009).

Pre-service teachers can gain experience through observing educators using technology and taking courses related to technology. In these kinds of courses available in teacher education programs, hands-on experience should also be included with the theoretical background provided. Considering all of these, pre-service teachers are enabled to design digital stories by using technology thanks to digital storytelling in the Instructional Technologies and Material Design (ITMD) course in the Department of Literacy Education. Digital storytelling allows users to employ technology in learning environments and prepare educational contents (Aktaş \& Uzuner Yurt, 2017). Additionally, it is thought that it would be beneficial to take opinions of pre-service teachers who are literacy educators on combining stories that are valuable for literacy education with digital storytelling supported by multimedia tools.

\section{Purpose of the study and research question}

The aim of this research is to examine the opinions of pre-service teachers, who will be mother language educators, about the use of digital storytelling in education. In line with this aim, pre-service teachers were allowed practice digital storytelling and their opinions were examined. In concert with this aim, this research question framed the study: 'What are the opinions of pre-service teachers about using digital storytelling in literacy education?' 


\section{Material and Method}

\section{Research model}

In this study, designed case study method from qualitative research models was used. Case study is a qualitative research methodology in which researcher explores and describes a phenomenon in detail and then reveals the themes of an event through triangulation to shed light on issues related to real life, to the existing system or to a certain period of time (Creswell, 2013). Case studies provide in-depth inquiry, time-based examination of conditions and coverage of contextual conditions (Yin, 2014). To that end, digital storytelling activity was conducted within the scope of ITMD course for eight weeks in this present study. Pre-service teachers designed digital stories as instructional materials according to curriculum goals. For each lesson, the researchers' field notes were taken, and pre-service teachers' reflections during the process were asked. Following the procedure, individual interviews on digital storytelling process were conducted with pre-service teachers.

\section{Participants}

A total of 32 sophomore pre-service teachers studying at Department of Literacy Education (Turkish Education) in Faculty of Education in a state university located in Central Anatolian Region during 2015-2016 academic year were recruited in this study. 22 of the participants were female. The cumulative grade point averages of 19 participants were between $0.0-2.5$ out of 4 , while 13 of them had between 2.6-4.0 grades.

\section{Data collection tools}

Interviews, field notes, document analyses, and observations are typical data collection tools in case studies from qualitative research models (Creswell, 2013; Creswell \& Plano Clark, 2011; Yin, 2014). In this study, a semi-structured form during interviews, students' reflections out of document analyses, and researcher's field notes coming from observations were all referred to as qualitative data collection instruments. In semi-structured interviews, open-ended questions can be asked, and the responses can be tape recorded to be transcribed, while it is possible to observe and take notes in the relevant environment (Creswell, 2013). There is a specific type of field note resorted to in case studies according to the results revealed following interviews, observations and document analyses (Yin, 2014). This type of field note was employed in this study. On the other hand, Cresswell (2012) notes that self-notes, letters and diaries of the participants are considered as documents too. Thereupon the participants were asked to submit self-reflections too.

\section{Semi-structured interview form}

This is a form developed by the researchers to examine the opinions of pre-service teachers towards digital storytelling in literacy education. The form was sent to field experts and then a pilot study was performed. The first version of the form included nine open-ended questions. After the revision, the form was revised, and two more items were added. The final version of the form included eleven questions. The interview form includes questions such as: "Did digital storytelling activities contribute to you?", "If so, how can you explain this contribution?", "According to you, what are the fundamental elements of a good digital story?", "What do you think about the applicability of digital stories in terms of literacy education?". 


\section{Students' reflections}

The participants were asked to submit reflections during the process. These reflections include their opinions on the activities done in the course, the difficulties they experienced and their coping strategies, favourite activities and general opinions.

\section{Researcher's field notes}

Field notes were taken by the researcher during the process. The researcher took notes on the difficulties observed during the course, circumstances occurring within or out of the scope of the procedure.

\section{Data analysis}

In qualitative studies, triangulation (using different and multi sources of information), long-term participation in the field and detailed description (describing the environment, participants and themes in detail) increase the validity of the study (Creswell \& Miller, 2000; Fraenkel \& Wallen, 2008). These three strategies of validity were employed in this research. Moreover, expert opinions and the pilot study while developing the interview form enhanced the validity of the research.

Recording the voices of the participants during the interviews and achieving agreement in coding process in the data analyses increase the reliability of the research in qualitative studies (Creswell, 2013; Fraenkel \& Wallen, 2008). In this context, the voices of the participants were tape recorded with full consent of the participants in this study and the agreement between two researchers during the coding process was calculated. This enhances the reliability of the research. Miles and Huberman (1994) suggest the formula "reliability=number of agreements/(number of agreements +disagreements)*100 for sufficient agreement among multiple coders and state that an inter-rater reliability (IRR) of $80 \%$ agreement is sufficient.

In this study, the content analysis technique was employed in the analysis of the participants' opinions, reflection reports and field notes of the researcher. First, the audiotape recordings of the participants during the individual interviews were transcribed. Also, the reflection reports of each participants were examined, considering the transcription of the interview. Following this, a transcription was coded by two coders and the codes were compared in terms of similarities and differences. The codes were discussed, and the coding table was formed. Two coders continued to code separately based on this coding table. The researcher continued to code alone when the sufficient agreement rate (88.2\%) was achieved. In the event of adding a new code, the researcher exchanged ideas with the second coder. Following the agreement, coding process continued. When it comes to field notes, similarities and differences were designed in tables and interpreted accordingly.

\section{Procedure}

The study includes two stages: The pilot study and the study. Prior to the procedure, an 18-hours pilot study was conducted. The pilot study was intended to check the applicability of the activities and see circumstances that may emerge during the process. After the pilot study, the necessary arrangements were made, and an 8-week procedure was performed. 


\section{Pilot study}

The pilot study was conducted with sixteen 3rd grade pre-service teachers studying at the Department of Literacy Education in the Faculty of Education in a state university during an 18-hours process. The steps offered by Cennamo et al. (2010) were followed while designing digital storytelling. GoAnimate (its current name is Vyond) web 2.0 tool was used to design digital stories. During the pilot study, the researcher's field notes and students' reflections were obtained. Following the practice, the opinions of the pre-service teachers were asked. Some changes were made in the procedure plan and data collection tools after the pilot study.

\section{The study}

The procedure was conducted in ITMD course for eight weeks in spring term of the 2015-2016 academic year. Figure 1 displays the implementation plan of digital storytelling.



Figure 1. Weekly implementation plan

The pre-service teachers designed digital stories as materials based on curriculum goals during the course. The pre-service teachers were provided with training on digital storytelling by the researcher. They were asked for designing digital stories considering the themes and objectives of the courses they would teach in related grades when they graduate and become in-service teachers. Beforehand, some general information on themes and objectives were given to the participants by an expert of Literacy Education. During the process, the opinions of the field expert were asked. While designing the digital stories during the implementations, the steps suggested by Cennamo et al. (2010) and displayed in Figure 2 were followed. The weekly implementation plan was developed according to these steps.



Figure 2. Steps of digital storytelling

The weekly implementation plan was developed by the researchers. After the opinions of the experts were taken, the pilot study was conducted, modifications such as limiting the word counts of the stories, expanding the time allocated to digital storytelling and assigning homework to make the students continue to study outside the classroom were made. Students' 
reflections were asked in every two weeks. The researcher took field notes in each lesson. Following the implementation, the participants were interviewed through the semi-structured form.

\section{Software to create digital story}

A wide range of software is being used, including PowerPoint, MovieMaker, iMovie, StoryBird, Powtoon, and GoAnimate to design digital stories. In this study, GoAnimate was used as it was thought that a software enabling its users to design digital stories in which they can modify the location, characters, music, and speeches and where they can make a story flow would be useful considering the age of the study group. Teacher can assign a username and a password to the students in GoAnimate software so that the students can design digital stories through their own usernames and passwords. The digital stories can be saved (downloaded) in MP4 format to be used later.

\section{Results}

This study focuses on the applicability of digital storytelling in literacy education. Based on the data from interview and reflection reports, themes, categories, codes and their frequencies are displayed in Table 1. Following the explanation of the table, similarities and differences between these results and field notes of the researcher are discussed.

Table 1. Opinions of pre-service teachers on digital storytelling

\begin{tabular}{|c|c|c|c|}
\hline Theme & Category & Code & $f$ \\
\hline \multirow{5}{*}{  } & \multirow{3}{*}{ Difficulties with software usage } & Dubbings & 23 \\
\hline & & Adjusting character movements & 18 \\
\hline & & Adjusting scenes & 11 \\
\hline & \multirow[t]{2}{*}{ Limitations of the software } & Using English Language & 22 \\
\hline & & Limited object variety & 10 \\
\hline \multirow{18}{*}{  } & \multirow[t]{11}{*}{ Contributions of digital storytelling } & Entertaining & 27 \\
\hline & & Permanent learning & 22 \\
\hline & & Improving writing skills & 17 \\
\hline & & $\begin{array}{l}\text { Course engagement (interest, motivation, } \\
\text { inspiration, taking attention...) }\end{array}$ & 17 \\
\hline & & A new method for teaching a subject & 13 \\
\hline & & Improving technology usage & 13 \\
\hline & & Addressing more sense organs & 12 \\
\hline & & Professional development & 11 \\
\hline & & Learning a new software & 11 \\
\hline & & Being practical in teaching boring subjects & 11 \\
\hline & & $\begin{array}{l}\text { Being practical in teaching difficult } \\
\text { subjects }\end{array}$ & 9 \\
\hline & \multirow[t]{3}{*}{ Difficult stages faced } & Using the software & 17 \\
\hline & & Writing a story & 15 \\
\hline & & Developing a storyboard & 9 \\
\hline & \multirow[t]{2}{*}{ Coping strategies with the difficulties } & Getting help from friends & 21 \\
\hline & & Getting help from instructor & 12 \\
\hline & \multirow[t]{2}{*}{ Weaknesses } & Time-consuming & 12 \\
\hline & & $\begin{array}{l}\text { Lack of technological infrastructure in } \\
\text { schools }\end{array}$ & 10 \\
\hline \multirow{5}{*}{  } & \multirow[t]{5}{*}{ Important elements for digital storytelling } & Scenario & 19 \\
\hline & & $\begin{array}{l}\text { Dubbing (speed, clearness, intelligibility, } \\
\text { emphasis, intonation, pronunciation) }\end{array}$ & 18 \\
\hline & & $\begin{array}{l}\text { Background music (sound level, suitability } \\
\text { with the event) }\end{array}$ & 12 \\
\hline & & Convenience for the target population & 12 \\
\hline & & Skill and knowledge of software & 11 \\
\hline
\end{tabular}




\begin{tabular}{|c|c|c|}
\hline & $\begin{array}{l}\text { Paying attention to grammar rules } \\
\text { Topic }\end{array}$ & $\begin{array}{l}11 \\
10\end{array}$ \\
\hline \multirow[t]{3}{*}{ Suitability for Turkish Language } & $\begin{array}{l}\text { The importance of learning with stories for } \\
\text { the field }\end{array}$ & 15 \\
\hline & $\begin{array}{l}\text { The importance of reading and writing in } \\
\text { the field }\end{array}$ & 9 \\
\hline & $\begin{array}{l}\text { Convenience for teaching Turkish subjects } \\
\text { (grammar, etc.) }\end{array}$ & 9 \\
\hline \multirow[t]{2}{*}{ Wishing to use in professional life } & $\begin{array}{l}\text { Using digital stories } \\
\text { himself/herself }\end{array}$ & 23 \\
\hline & Making the students design digital stories & 15 \\
\hline
\end{tabular}

As shown in Table 1, the qualitative data were classified under three themes, nine categories and thirty-five codes.

\section{Software usage}

Based on the findings, there were two categories i.e. difficulties with software usage and limitations of the software, and five codes under these categories. This theme includes opinions of pre-service teachers on the software for digital storytelling activities. In addition to use of such software such as PowerPoint, MovieMaker, and PhotoStory, there are others including GoAnimate and Powtoon that allow their users to use characters. In this study, GoAnimate, a web 2.0 tool, was made use of as it was thought that a software which enables its users to design digital stories in which they can modify the location, characters, music, speeches and can make a story flow will be useful considering the age of the study group. The selection of the most suitable software for the target population is one of the key factors in digital storytelling. In this regard, it can be noted that a very simple software may cause users to get bored, just as a difficult one is likely to lead to difficulties, thereby causing negative attitudes towards the software. It would be useful to focus on studies including different types of software and the opinions of the participants to determine which software are useful for what age groups.

There are three codes under the difficulties with software usage category. The most repeated code among these is dubbings $(\mathrm{f}=23$ ). An example expression is as follows: (The participants were coded as $\mathrm{P} 1, \mathrm{P} 2, \ldots)$.

"I had difficulty in finding the right person for dubbing as there were a lot of characters. Anyway, those people had difficulty in dubbing, as well. They either burst into laughter or made wrong emphasis or used wrong intonations while dubbing..." P3

There are two codes in limitations of the software category. The most repeated code among these is using English Language $(\mathrm{f}=22)$. An example expression is as follows:

"I had difficulty finding the things for which I looked. For example, we had difficulty in finding some words including garden instead of classroom environment or clothes for the characters due to lack of English proficiency. However, it was a good work in general." P23

\section{Positive and negative aspects}

Based on the findings, there emerge four categories: contributions of digital storytelling, difficult stages faced, coping strategies with the difficulties, and the weaknesses of digital stories and eighteen codes. This theme includes positive and negative opinions of participants based on their experiences with digital storytelling. Focusing on experiences of 
implementation and revealing the opinions of the participants through interviews and selfreflections will contribute to a better implementation. Each piece of research may disclose distinctive findings that cannot otherwise be revealed in others.

There are eleven codes under the contributions of digital storytelling category. The most repeated code is entertaining ( $\mathrm{f}=27$ ). This code shows that the pre-service teachers enjoyed the process while designing digital stories and regarded this as the most important contribution. An example expression is as follows:

"It is a rather entertaining and enjoyable software. I loved it. I had difficulty, but I am happy. This helped me focus on being successful, maintaining it rather than giving up. I see it as a beneficial activity." P26

There are three codes under the difficult stages faced. The most repeated code is using the software ( $f=17$ ). This code shows that the pre-service teachers had often difficulty in using the software. An example expression is as follows:

"I had difficulty in using the software. Others aren't much difficult as this, but I had problems since it was the first time I used this software." P28

There are two codes under the coping strategies with the difficulties. The most repeated code is getting help from friends $(f=21)$. This code shows that the pre-service teachers mostly ask for help from their friends when they had trouble. An example expression is as follows:

"When I couldn't find the tools and had problems with using the software, I asked for help from my friends." P19

There are two codes under the weaknesses of digital storytelling. The most repeated code is that designing a digital story is time-consuming $(\mathrm{f}=12$ ). This code shows that the pre-service teachers consider the time spent during digital storytelling as one of the weaknesses of the software. An example expression is as follows:

"If the teacher designs a digital story, it may take longer periods of time. The topic may not be integrated into the curriculum." P15

\section{Use at literacy education}

Based on the findings, there emerge three categories: important elements for digital storytelling, suitability for Turkish language and wishing to use in professional life and twelve codes under these categories. This theme includes opinions of pre-service teachers on using digital storytelling in literacy education. It can be noted that digital storytelling is a more convenient method for verbal courses as self-expression, writing and stories are significant in verbal fields like literacy, history. Therefore, in this study, the pre-service teachers who would teach literacy in the future were recruited as the study group.

There are seven codes reported as important elements for digital storytelling. The most repeated code is scenario $(\mathrm{f}=19)$. This code shows that the pre-service teachers consider the scenario as the most important thing to design a digital story in their own professions. An example expression is as follows: 
"First of all, there must be a nice idea and a well-written scenario. The scenario must be attractive and easy so much so that it can be animated in the digital story effectively and without difficulty." P2

There are three codes under suitability for Turkish language category. The most repeated code is the importance of learning with stories for the field $(f=15)$. This code shows that the preservice teachers consider the digital storytelling as significant in terms of its applicability in their profession. An example expression is as follows:

"...Stories are materials to be used for literacy activities, and so they are important for literacy education and Turkish lessons. " P5

There are two codes under wishing to use digital stories in professional life category. The most repeated code is using digital stories prepared by himself/herself ( $f=23$ ). This code shows that the pre-service teachers wish to broadcast the digital stories designed by themselves to be watched by others. An example expression is as follows:

"I certainly use it while teaching and prefer to design it by myself. I would design it to teach the complicated issues of the subject since I know better when students have difficulty." P6

When the field notes of the researcher are examined, Table 2 summarizes the most remarkable points.

Table 2. Findings on process by field notes of the researcher

\begin{tabular}{ll}
\hline Problems & $\begin{array}{l}\text { Having difficulty in dubbing the stories } \\
\text { Time problems caused by technical issues }\end{array}$ \\
\hline \multirow{3}{*}{ Requirements } & Software including Turkish Language \\
& Getting help from friends \\
& Guidance \\
& Want to learn the software by other pre-service teachers \\
\hline Personal development & Improving communication skills \\
& Increasing self-confidence in writing \\
& Increasing self-confidence in technology usage \\
& The contribution of different practices to professional development \\
& Increasing the engagement in the lesson \\
\hline
\end{tabular}

As shown in Table 2, the field notes of the researchers were classified under three categories, including problems experienced in the process, requirements for the implementation, and contributions to the personal development. In this sense, it can be underlined that the findings of interviews and reflections concur well with the field notes.

\section{Discussion}

This study sought to contribute to a growing body of studies hence the bulk of literature in digital storytelling field. The results provide evidence to suggest that digital storytelling enhances the communication among pre-service teachers and between them and the instructor, provides cooperation, makes the lessons more entertaining and increases the engagement during the lesson. Yet there may be some difficulties with dubbings and the language of the software, in addition to some time delays due to technical issues. The results announced that digital storytelling will contribute to literacy education as Turkish is a verbal 
field, and digital storytelling is a convenient method for literacy education in terms of its significance for speaking, writing and communicating with visual images. Furthermore, the participants mentioned that they were eager to use digital storytelling in literacy education. It was also found that they considered scenario, dubbing and suitability for the target population as important issues while designing digital stories. Semingson et al. (2016) argued that there are is a wide range of software to design digital stories, but it is of importance to find a suitable one for the age and grade levels of the students bearing in mind the complexity of the software.

A review of the literature has shown that there are some studies that corroborated with the findings of this research. In one of these studies, Aktaş and Uzuner Yurt (2017) concluded that Turkish pre-service teachers had difficulty in dubbing and creating stories while designing a digital story. The authors also found that digital storytelling contributed to motivations, and promoted permanent learning, technology use skills and writing skills. In another study by Del-Moral et al. (2016), it was concluded that the participants experienced difficulty in creating the scenario and making the pronunciations of the words in dialogues while designing digital stories although they improved written and verbal communication skills, narration skills and digital competences. Ekmekçi (2016) concludes that digital storytelling can improve information and communication technology literacy skills in foreign language education. The work of Tatli and Aksoy (2017) is in good agreement with this present study in that university students had difficulty in dubbing in foreign language education, while it developed technological skills of the participants. In their study by Walters, Green, Goldsby and Parker (2018) with pre-service teachers stated that the participants shared digital storytelling would increase their own students' understanding of content, engagement and motivation.

Based on the findings, it can be noted that the pre-service teachers found the activity as entertaining, and wished to employ it in the future even though they reported that they had difficulty in finding the right person or silent environment for dubbing and had problems with looking for the meanings of the words they faced in the software. On the other hand, designing a digital story was found as time-consuming by the participants and this was evaluated as a weakness of the digital storytelling. This may have resulted from the fact that they used such a software for the first time, the English language of the software, finding the appropriate person or silent environment for dubbing was rather difficult or this could be something to do with some rare technical impediments. There is evidence to suggest that the participants mostly had difficulty in using the software. This may also have caused by the fact that it was a new experience for the pre-service teachers to use a software like this, owing to time-consuming steps or technical problems and the software language. In this sense, Karakoyun and Kuzu (2016) lend support this, by noting that the participants needed technical support and the implementation was a time-consuming process. Balaman (2016) concurs well with this, by suggesting that the students had difficulty in digital storytelling as they used the software for the first time. Sadik (2008) also is aligned with the findings of this study. The author concluded that the participants stated that digital storytelling help the learners understand the topic better, and that digital storytelling enhances the cooperation and communication, but they may need technical support during this process. Here it can be noted that providing users with technical support before designing digital stories and compensating their software and hardware needs will contribute to the overall process.

Being critical elements of a good digital story, the scenario and dubbing are of great importance since the message intended to be transmitted to the students is hidden in the 
scenario. All elements in a scenario, including characters, events and results will have an impact on the quality of the digital story. It was also detected that the participants consider the software as convenient in terms of Turkish language since it is important to teach through stories in literacy education. Wan et al. (2008), language education is one of the most significant field for using digital storytelling. Leong, Abidin and Saibon (2019) concluded that digital storytelling has positive effects on vocabulary learning.

Digital storytelling can be a powerful educational tool for students from each age and grade level who intend to create their own digital stories (Robin, 2016). Based on the results of this study, it can be pinpointed that using digital storytelling in teacher education programmes will yield positive outcomes. This is particularly essential in literacy education since time, written texts, and stories play fundamental roles in literacy education. For this reason, using this technology that is effective on writing skills of pre-service teachers who will teach literacy will contribute to their professional development. Upon graduating, they will be more competent in ensuring the gaining of this skill by their students.

\section{Conclusion}

This study has sought to illuminate the applicability of digital storytelling in literacy education. For this purpose, the pre-service teachers designed digital stories using the software and their opinions were asked. Based on the findings, it was discovered that digital storytelling develops the communication among pre-service teachers, and between them and the instructor, provides cooperation, makes the lessons more entertaining, increases the engagement during the lesson, and improves written expression and technology use skills. Notwithstanding, there were some difficulties with the language of the software and dubbings, some time delays occurred due to technical impediments as well as there were a number of time-consuming steps. It was pinpointed that digital storytelling contributes to literacy education as Turkish is a verbal field, and digital storytelling is a convenient method for literacy education in terms of its significance for speaking, writing and visual images. They considered the scenario, the quality of dubbing, and the convenience for the target population to design a good digital story. The pre-service teachers were willing to use digital storytelling while teaching in the future.

\section{Limitation and recommendations}

Although the results of this study provide compelling evidence, we are aware of the fact that our research may have limitations as it is the case in any study related to social fields. First, English language used in software can be considered as a limitation in the study since this might have meant spending more time and making more effort for those students with beginner levels of English. Another limitation is that the convenient and small sample of the pre-service teachers limits the generalization of the results to other contexts and populations.

\section{Recommendations for researchers}

Despite the above limitations, this study has specific recommendations. Correspondingly, future studies on the current topic are recommended in terms of two dimensions. The first is that it has been determined that very few software are accessible which provide the users with character and moving items while designing digital stories. What is more, there are very few language choices in software. Considering these points, the software to develop digital stories can be created by following software development and formative research principles. The second is that it is necessary to take the support of related 
field experts as well as those with technological expertise while conducting studies. Taking this into account literacy teaching experts as well as those with technological proficiency were asked for help if necessary, in this research. Exchanging ideas with the experts in literacy education in which stories are key may add new perspectives to the studies. For this reason, new studies on digital storytelling can be designed with the help of field experts.

\section{Recommendations for practitioners}

In this study, there are also several recommendations for the teachers and educational institutions which train teachers. First, selecting the software to be used in digital storytelling calls for great attention. There is a wide range of software services for designing digital stories, but students are more attracted by those in which they can use characters and add to movements to the characters. The number of the software services that allow its users to do these is limited or there no language option given. Given these, the software services where digital stories can be designed by using the moving characters and that provide language option support should be used. The second one is that it is necessary to check the technological infrastructure so that any potential problems can be determined before the digital storytelling practices. As long as the problems remain unsolved, time delay problems and loss of motivation may take place. Finally, finding a silent environment during dubbing is another significant issue in designing digital storytelling. This is not always easy and hence dubbing may not be possible during the lesson. To eliminate this problem, students should be assisted in their seeking the necessary equipment and sources as computers, internet, audio tape recorder, microphone or should be allowed to use the computer labs in their spare times.

\section{Acknowledgement}

This research is a part of first author's doctoral thesis with second author's consultancy at Gazi University, Institute of Educational Sciences.

\section{References}

Aktaş, E., \& Uzuner Yurt, S. (2017). Effects of digital story on academic achievement, learning motivation and retention among university students. International Journal of Higher Education, 6(1), 180-196.

Bağc1, H. (2010). Levels of Turkish teacher candidates' efficiency of written expression. Inonu University Journal of the Faculty of Education, 11(2), 45-68.

Balaman, F. (2016). The effect of digital storytelling technique on the attitudes of students toward teaching technologies. Pegem Journal of Education and Instruction, 6(2), 147168.

Batar, M., \& Aydın, İ. S. (2014). Evaluation of Turkish teacher candidates' self efficacy beliefs of written expression. International Journal of Language Academy, 2(4), 579598.

Çakır, R., \& Yıldırım, S. (2009). What do computer teachers think about the factors affecting technology integration in schools? Elementary Education Online, 8(3), 952-964.

Cennamo, K., Ross, J., \& Ertmer, P. (2010). Technology integration for meaningful classroom use. A standard-based approach. Belmont, CA: Wadsworth.

Ciğerci, F. M., \& Gultekin, M. (2017). Use of digital stories to develop listening comprehension skills. Issues in Educational Research, 27(2), 252-268.

Çıralı Sarıca, H., \& Koçak Usluel, Y. (2016). The effect of digital storytelling on visual memory and writing skills. Computers \& Education, 94, 298-309. 
Çocuk, H. E., \& Yanpar Yelken, T. (2018). The effect of the web-based digital story applications on the digital literacy levels of Turkish teacher candidates. Asian Journal of Education and Training, 4(2), 132-136.

Creswell, J. W. (2012). Educational research: Planning, conducting, and evaluating quantitative and qualitative research. Boston, MA: Pearson Education.

Creswell, J. W. (2013). Qualitative inquiry \& Research design: Choosing among five approaches. United States of America: SAGE.

Creswell, J. W., \& Plano Clark, V. L. (2011). Designing and conducting mixed methods research. United States of America: SAGE.

Del-Moral, M. E., Villalustre, L., \& Neira, M. R. (2016). Digital storytelling: Activating communicative, narrative and digital competences in initial teacher training. Ocnos, $15,22-41$.

Dogan, B. (2007). Implementation of digital storytelling in the classroom by teachers trained in a digital storytelling workshop. (Unpublished Doctoral Dissertation). University of Houston, Houston.

Egbert, J., Huff, L., Mcneil, L., Preuss, C., \& Sellen, J. (2009). Pedagogy, process, and classroom context: Integrating teacher voice and experience into research on technology-enhanced language learning. The Modern Language Journal, 93, 754-768.

Ekmekçi, E. (2016). Improving English as a foreign language (EFL) learners' ICT literacy skills through digital storytelling. Participatory Educational Research (PER), Special Issue, 1-9.

Fraenkel, J. R., \& Wallen, N. E. (2008). How to design and evaluate research in education. Boston, MA: McGraw-Hill.

France, D., \& Wakefield, K. (2011). How to produce a digital story. Journal of Geography in Higher Education, 35(4), 617-623.

Garrety, C. M. (2008). Digital storytelling: An emerging tool for student and teacher learning. (Unpublished Doctoral Dissertation). Iowa State University, Ames, Iowa.

Leong, A. C. H., Abidin, M. J. Z., \& Saibon, J. (2019). Learners'perceptions of the impact of using digital storytelling on vocabulary learning. Teaching English with Technology, 19(4), 3-26.

Hewson, J., Danbrook, C., \& Sieppert, J. (2015). Engaging post-secondary students and older adults in an intergenerational digital storytelling course. Contemporary Issues in Education Research, 8(3), 135-142.

Kajder, S., Bull, G., \& Albaugh, S. (2005). Constructing digital stories. Learning \& Leading with Technology, 32(5), 40-42.

Karakoyun, F., \& Kuzu, A. (2016). The investigation of preservice teachers' and primary school students' views about online digital storytelling. European Journal of Contemporary Education, 15(1), 51-64.

Keşli Dollar, Y., \& Tekiner Tolu, A. (2015). My first digital story: A case study with 5th grade Turkish English language learners. ELT Research Journal, 4(3), 172-185.

Lemon, N., \& Garvis, S. (2016). Pre-service teacher self-efficacy in digital technology. Teachers and Teaching, 22(3), 387-408.

Mayer, R. E. (2003). The promise of multimedia learning: using the same instructional design methods across different media. Learning and Instruction, 13(2), 125-139.

Miles, M. B., \& Huberman, A. M. (1994). Qualitative data analysis: An expanded sourcebook. Thousand Oaks, CA: Sage.

Ng, W., \& Nicholas, H. (2015). iResilience of science pre-service teachers through digital storytelling. Australasian Journal of Educational Technology, 31(6), 736-751.

Robin, B. R. (2006). The educational uses of digital storytelling. In C. Crawford, R. Carlsen, K. McFerrin, J. Price, R. Weber \& D. Willis (Eds.), Proceedings of society for 
information technology \& Teacher education international conference (pp. 709-716). Chesapeake, VA: AACE.

Robin, B. R. (2016). The power of digital storytelling to support teaching and learning. Digital Education Review, 30, 17-29.

Robin, B. R., \& Pierson, M. (2005). A Multilevel approach to using digital storytelling in the classroom. In C. Crawford, R. Carlsen, I. Gibson, K. McFerrin, J. Price, R. Weber \& D. Willis (Eds.), Proceedings of society for information technology \& Teacher education international conference (pp. 708-716). Chesapeake, VA: AACE.

Sadik, A. (2008). Digital storytelling: A meaningful technology-integrated approach for engaged student learning. Educational Technology Research and Development, 56(4), 487-506.

Semingson, P., Hurlbut, A., Owens, D., \& Robertson, M. (2016). Scaffolding digital writing and storytelling in online-only teacher education courses. In J. Keengwe \& G. Onchwari (Eds.), Handbook of research on learner-centered pedagogy in teacher education and professional development (pp. 104-127). Hershey PA: Information Science References.

Sezginsoy Şeker, B. (2016). An evaluation of digital stories created for social studies teaching. Journal of Education and Practice, 7(29), 18-29.

Smeda, N., Dakich, E., \& Sharda, N. (2014). The effectiveness of digital storytelling in the classrooms: A comprehensive study. Smart Learning Environments, 1(6), 1-21.

Suwardy, T., Pan, G., \& Seow, P.-S. (2012). Using digital storytelling to engage student learning. Accounting Education: An International Journal, 22(2), 109-124.

Tatl1, Z., \& Aksoy, D. A. (2017). Using digital storytelling in foreign language speaking education. Marmara University Atatürk Education Faculty Journal of Educational Sciences, 45, 137-152.

Walters, L.M., Green, M.R., Goldsby, D., \& Parker, D. (2018). Digital storytelling as a problem-solving strategy in mathematics teacher education: How making a math-eo engages and excites 21 st century students. International Journal of Technology in Education and Science (IJTES), 2(1), 1-16.

Wan, G., Tanimoto, R., \& Templeton, R. A. (2008). Creating constructivist learning environment for Japanese EFL Students: A digital story program. The Asian EFL Journal Quarterly, 10(2), 31-50.

Xu, Y., Park, H., \& Baek, Y. (2011). A new approach toward digital storytelling: An activity focused on writing self-efficacy in a virtual learning environment. Educational Technology \& Society, 14(4), 181-191.

Yamaç, A., \& Ulusoy, M. (2016). The effect of digital storytelling in improving the third graders' writing skills. International Electronic Journal of Elementary Education, 9(1), 59-86.

Yin, R. K. (2014). Case study research: Design and methods. Washington DC: Sage. 